\title{
In vitro transfer of methicillin resistance determinants mecA from methicillin resistant Staphylococcus aureus (MRSA) to methicillin susceptible Staphylococcus aureus (MSSA)
}

\author{
Asinamai Athliamai Bitrus' ${ }^{1}$ Zakaria Zunita ${ }^{1 *}$, Siti Khairani Bejo ${ }^{1}$, Sarah Othman² and Nur Adilah Ahmad Nadzir ${ }^{1}$
}

\begin{abstract}
Background: Staphylococcus aureus more than any other human pathogen is a better model for the study of the adaptive evolution of bacterial resistance to antibiotics, as it has demonstrated a remarkable ability in its response to new antibiotics. This study was designed to investigate the in vitro transfer of mecA gene from methicillin resistant $S$. aureus to methicillin susceptible $S$. aureus.

Result: The recipient transconjugants were resistant to erythromycin, cefpodoxime and were mecA positive. PCR amplification of mecA after mix culture plating on Luria Bertani agar containing $100 \mu \mathrm{g} / \mathrm{mL}$ showed that $75 \%$ of the donor and $58.3 \%$ of the recipient transconjugants were mecA positive. Additionally, $61.5 \%$ of both the donor cells and recipient transconjugants were mecA positive, while $46.2 \%$ and $41.75 \%$ of both donor and recipient transconjugants were mecA positive on LB agar containing $50 \mu \mathrm{g} / \mathrm{mL}$ and $30 \mu \mathrm{g} / \mathrm{mL}$ respectively.

Conclusion: In this study, the direction of transfer of phenotypic resistance as well as mecA was observed to have occurred from the donor to the recipient strains. This study affirmed the importance of horizontal transfer events in the dissemination of antibiotics resistance among different strains of MRSA.
\end{abstract}

Keywords: Antibiotics, Horizontal gene transfer, Methicillin, Resistance, Staphylococcus aureus

\section{Background}

Staphylococcus aureus is a good model better than any other human pathogen that exemplifies the successful adaptation to the therapeutic effect of antibiotics as it has demonstrated a unique ability in rapidly acquiring resistance to new antibiotics. It is one of the pathogens though extensively studied but yet, still surprises us with new and dynamic means of antibiotic resistance development.

The increase in antimicrobial resistance has coincided with the rate of widespread use of antibiotics. A strong selection pressure towards resistance among bacteria was promoted by the application of antibiotics in the

\footnotetext{
* Correspondence: zunita@upm.edu.my

${ }^{1}$ Faculty of Veterinary Medicine, Universiti Putra Malaysia, 43400 UPM

Serdang, Malaysia

Full list of author information is available at the end of the article
}

fields of veterinary and human medicine as well as in animal husbandry [1]. It has been observed that the management of infectious disease is greatly threatened by the increase in the prevalence of antibiotic-resistant pathogens. Factors responsible for the development of resistance are associated with mobile genetic elements carrying genomic islands such as conjugative plasmids and transposons which are known to facilitate the transfer of resistance genes to other bacteria through horizontal gene transfer [2]. There is an increasing concern with regards to the emergence of MRSA as a common cause of hospital-acquired infections. This is because, majority of MRSA strains are multi-resistant, a feat achieved by the acquisition of extra resistance determinants such as conjugative plasmid carrying gentamicin resistance [2]. 
The site specific integration of the staphylococcus cassette chromosomes mec (SCCmec) into the genome of $S$. aureus at a region called the $S C C m e c$ insertion or attachment site is facilitated by a cassette chromosome recombinase $(c c r)$ gene. [3, 4]. These recombinases function as dimers which in the case of $\operatorname{cr} A B$, facilitates the integration of $S C C m e c$ into the chromosome of $S$. aureus. This is achieved by attaching it to the core recognition site, one on the staphylococcal chromosome and the other on the SCCmec itself (attB and attSCC) [5]. The $a t t B$ is a 15 base pair sequence found on the chromosomal end in the open reading frame of unknown origin ( $\operatorname{orf} \mathrm{X})$ also known as the universal integration site for $S C C m e c$. The integration of the SCCmec into the genome culminates into the formation of two hybrid site at either ends of the SCCmec dubbed the attL and the $a t t R$ [5]. It is well-established that methicillin susceptible $S$. aureus (MSSA) became methicillin resistant $S$. aureus (MRSA) following the acquisition of genomic island carrying methicillin resistance determinant mecA [6]. However, the evolutionary origin as well as detail mechanism of transfer mecA is not fully understood $[4,7,8]$.

In general, there are no studies available on the molecular investigation on antibiotic resistance transfer between MRSA and MSSA using isolates from human and animals and at different concentration of antibiotic marker. The increase in the emergence of highly pathogenic strains of methicillin resistant $S$. aureus and its impact on public health is becoming a major problem for prevention and control of MRSA. It is important therefore to investigate the mechanism of in vitro antibiotic resistance transfer and the role it plays in the emergence of highly resistant strains with a view to ensure effective prevention and control of $S$. aureus infection. This study was designed to investigate the in vitro transfer of methicillin resistance determinant mecA from MRSA to MSSA using mix liquid culture plating and PCR amplification of methicillin resistance gene $m e c \mathrm{~A}$ and $\operatorname{orf} \mathrm{X}$.

\section{Methods}

Bacterial strains and culture conditions

Six (6) methicillin resistant $S$. aureus (MRSA) and four (4) methicillin susceptible $S$. aureus (MSSA) strains isolated from humans ( $\mathrm{SH} 1, \mathrm{SH} 4$ and $\mathrm{SH} 8$ ), animals (SDG2, SDG3, SDG4, SEQ1, SEQ5 and SCH4) and environment (SEV1) obtained from previous studies as reported by Aklilu et al. [9, 10] were used in this experiment. The isolates were collected from 2008 to 2011 from cats and dogs, DVM students and veterinary personnel and were identified as $S$. aureus using biochemical test and Staphylococcus identification kit, Staphytect plus(R) (Oxoid, UK) and Dry spot ${ }^{\mathrm{TM}}$ Staphytect plus (DR0100M, UK) according to the manufacturers recommendation before they were stored in cryobeads tubes at $-80{ }^{\circ} \mathrm{C}$ as stock cultures. The cryobeads were thawed at room temperature before enrichment in tryptic soy broth and culturing onto a blood agar containing 5\% horse. Presumptive isolates were reconfirmed as $S$. aureus by catalase and tube coagulase test as well as PCR amplification of thermostable nuclease gene $(n u c)$. Phenotypic confirmation of MRSA was done by culturing on Oxacillin Resistance Screening Agar Base media (ORSAB) (Oxoid Basingstoke, UK) while genotypic confirmation was carried out by PCR amplification of methicillin resistance determinant mecA and SCCmec types. The recipient cells were also screened for the presence orf $X$ - SCCmec integration site.

\section{Selection of donor and recipient cells}

Donor and recipient cells were purposely selected based on their resistance profile, presence and absence of methicillin resistance determinant $m e c \mathrm{~A}, \mathrm{SCC} m e c$ types as well as availability of isolates with distinct antibiotic marker (Table 1). The donor cells were selected based on presence

Table 1 Oligonucleotide sequence for the amplification of mecA, orfX and SCCmec types

\begin{tabular}{|c|c|c|c|c|c|}
\hline $\mathrm{S} / \mathrm{N}$ & Primer & Oligonucleotide sequence 5'to 3' & Product size & Annealing temperature & Reference \\
\hline \multirow[t]{2}{*}{1} & mecAF mecAR & ACTGCTATCCACCCTCAAAC & $163 \mathrm{bp}$ & $57^{\circ} \mathrm{C} / 120 \mathrm{~s}$ & Noto. [27]; Mehrotra et al. [28] \\
\hline & & CTGGTGAAGTTGTAATCTG & & & \\
\hline \multirow[t]{2}{*}{2} & Nuc-F & GCG ATT GAT GG TGA TAC GGT T & $276 \mathrm{bp}$ & $55^{\circ} \mathrm{C} / 120 \mathrm{~s}$ & Saiful et al. [29] \\
\hline & Nuc- $R$ & AGC CAA CGG TTG ACG AAC TAA AGC & & & \\
\hline \multirow[t]{2}{*}{3} & OrfX F & GAG AAA TAT TGG AAG CAA GCC & $326 \mathrm{bp}$ & $54.6^{\circ} \mathrm{C} / 60 \mathrm{~s}$ & Noto. [27] \\
\hline & OrfX R & CGC ATA ATC TTA AAT GCT CTG & & & \\
\hline \multirow[t]{2}{*}{4} & SCCmedIIIFSCCmedIIIR & TTC TCA TTG ATG CTG AAG CC & $280 \mathrm{bp}$ & $55^{\circ} \mathrm{C} / 60 \mathrm{~s}$ & Zhang et al. [30] \\
\hline & & GTG TAA TTT CTT TTG AAA GAT ATG G & & & \\
\hline \multirow[t]{2}{*}{5} & mecA F & 5'-ACTGCTATCCACCCTCAAAC-3' & $533 \mathrm{bp}$ & $55^{\circ} \mathrm{C} / 120 \mathrm{~s}$ & Saiful et al. [29] \\
\hline & mecA R & 5'-CTGGTGAAGTTGTAATCTGG-3' & & & \\
\hline
\end{tabular}


of mecA, type of SCCmec and susceptibility to tigecycline and levofloxacin but resistant to erythromycin and cefpodoxime. On the other hand, the recipients cells were mecA negative and resistant to tigecycline, levofloxacin but susceptible to erythromycin and cefpodoxime.

\section{Antibiotic resistance profile of bacterial strains}

The antibiotic susceptibility profiles of the studied isolates were determined using disk-diffusion method as described by Bauer et al. [11]. The diameter of the zone of inhibition was measured using a digital Vernier caliper and interpreted according to the guidelines of Clinical Laboratory Standard Institute (CLSI) [12]. Susceptibility of the isolates were determined by testing each isolate against oxacillin $1 \mu \mathrm{g}$, cefoxitin $30 \mu \mathrm{g}$, cefpodoxime $10 \mu \mathrm{g}$, erythromycin $15 \mu \mathrm{g}$, amoxicillin $25 \mu \mathrm{g}$, tigecycline $15 \mu \mathrm{g}$, levofloxacin $1 \mu \mathrm{g}$ and neomycin $10 \mu \mathrm{g}$.

\section{Transfer of antibiotic resistance in mixed liquid cultures}

Fresh bacterial cultures were grown in Luria-Bertani broth (LB broth) at $30{ }^{\circ} \mathrm{C}$ for $12 \mathrm{~h}$ without shaking. Aliquot of $200 \mu \mathrm{L}$ volume of each donor MRSA cells (resistant to erythromycin and cefpodoxime but susceptible to tigecycline and levofloxacin) and recipient MSSA cells (resistant to tigecycline and levofloxacin but susceptible to erythromycin and cefpodoxime) were adequately mixed in $1.5 \mathrm{~mL}$ microcentrifuge tube. The cultures were amplified with another $200 \mu \mathrm{L}$ of $\mathrm{LB}$ broth and incubated for $6 \mathrm{~h}$ at $37{ }^{\circ} \mathrm{C}$. Fifty microliter $(50 \mu \mathrm{L})$ of the mixed cultures containing $10^{5}$ colony forming unit $(\mathrm{CFU} / \mathrm{mL})$ were drawn and plated on separate $\mathrm{LB}$ agar containing $100 \mu \mathrm{g} / \mathrm{mL}$ of erythromycin, tigecycline, cefpodoxime and levofloxacin. The procedure was repeated on LB agar containing $50 \mu \mathrm{g} / \mathrm{mL}$ and $30 \mu \mathrm{g} / \mathrm{mL}$ of the same antibiotics respectively and incubated for $24 \mathrm{~h}$ at $37^{\circ} \mathrm{C}$. After $24 \mathrm{~h}$, colonies that grow on LB agar containing erythromycin or cefpodoxime were picked as the donors while those that grow on tigecycline or levofloxacin were picked as recipients' transconjugants. The choices of these antibiotics were made on purpose so that the resistant colonies might represent the transconjugants where the transfer of methicillin resistance determinant mecA had taken place from the donor to recipient strains. Three to four colonies were picked from each of the plates and then inoculated in a freshly prepared LB broth and incubated overnight.

\section{DNA extraction}

Genomic DNA was extracted from overnight fresh cultures by boiling method as described by Chen et al. [13]. A loopful suspension of overnight grown cultures was prepared in a $1.5 \mathrm{~mL}$ microcentrifuge tube containing $100 \mu \mathrm{L}$ of sterile distilled water. The suspension was first incubated at room temperature for $5 \mathrm{~min}$, and then heated in a dry bath at $96{ }^{\circ} \mathrm{C}$ for $10 \mathrm{~min}$. The suspension was centrifuged at $13,000 \mathrm{rpm}$ for $5 \mathrm{~min}$, the supernatant was collected in a new microfuge tube and used as DNA template.

\section{Polymerase chain reaction (PCR) assay}

PCR amplification of gene fragments of mecA (163 bp), orfX (356 bp) and SCCmec types was performed using specific primers and annealing cycling conditions as described in Table 1. All reactions were carried out in a thermal cycler (BIO-RAD) at initial denaturation temperature of $94{ }^{\circ} \mathrm{C}$ for $5 \mathrm{~min}$, followed by 30-37 cycles of denaturation at $94{ }^{\circ} \mathrm{C}$ for $1 \mathrm{~min}$, elongation at $72{ }^{\circ} \mathrm{C}$ for $1 \mathrm{~min}$ and final elongation at $72{ }^{\circ} \mathrm{C}$ for $5 \mathrm{~min}$. The reaction was carried out in a $50 \mu \mathrm{L}$ reaction volume which contained $5 \mu \mathrm{L}$ genomic DNA, Toptaq master mix $25 \mu \mathrm{L}$ (Qiagen), containing DNA polymerase, PCR Buffer (with $3 \mathrm{mM} \mathrm{MgCl}$ ), and $400 \mu \mathrm{M}$ each dNTPs, $10 \times$ coral load $5 \mu \mathrm{L}$ (Qiagen); $1 \mu \mathrm{L}(0.1 \mu \mathrm{M})$ of each forward and reverse primer (Integrated DNA technologies, Singapore) and $13 \mu \mathrm{L}$ of RNase free water (Qiagen).

\section{Agarose gel electrophoresis}

Electrophoresis of the amplified PCR products was carried out in $2 \%$ agarose (Sigma-Aldrich) prepared in a $0.5 \mathrm{X}$ Tris-Borate EDTA (TBE) buffer. Ten microliter $(10 \mu \mathrm{L})$ of PCR product each was loaded in a well of submerged gel. The PCR products were then subjected to electrophoresis at $80 \mathrm{~V}$ for $90 \mathrm{~min}$. The gel was stained with Gel Red (Invitrogen) $2 \mu \mathrm{L} / 100 \mathrm{~mL}$ of agarose gel. The stained electrophoresed PCR products were visualized under the transilluminator UV-light using a gel documentation system alpha imager (BIO-RAD).

\section{Sequencing of mecA gene to validate the transfer events}

Amplified chromosomal DNA containing the gene fragment of mecA (Fig. 1a and b) were sequenced using the BigDye $^{(\mathrm{R})}$ Terminator v3.1 cycle sequencing kit (Applied Biosystems, USA). The electropherograms of the DNA sequence obtained from the eight isolates were checked for any ambiguity using BioEdit v7.0.9 [14]. The derived sequences were then subjected to multiple alignment sequence as in ClustalX (http://www.clustal.org/clustal2/) [15] using default parameters in order to obtain a consensus sequence. The consensus nucleotide fragments were then translated to protein using translating tool ExPasy (http://web.expasy.org/translate/) [16] and the open reading frame with was detected. This is to ensure that the mecA sequence were genuine and not due to errors arising from PCR which may introduce a shift in the frame and stop codons in the sequence. 

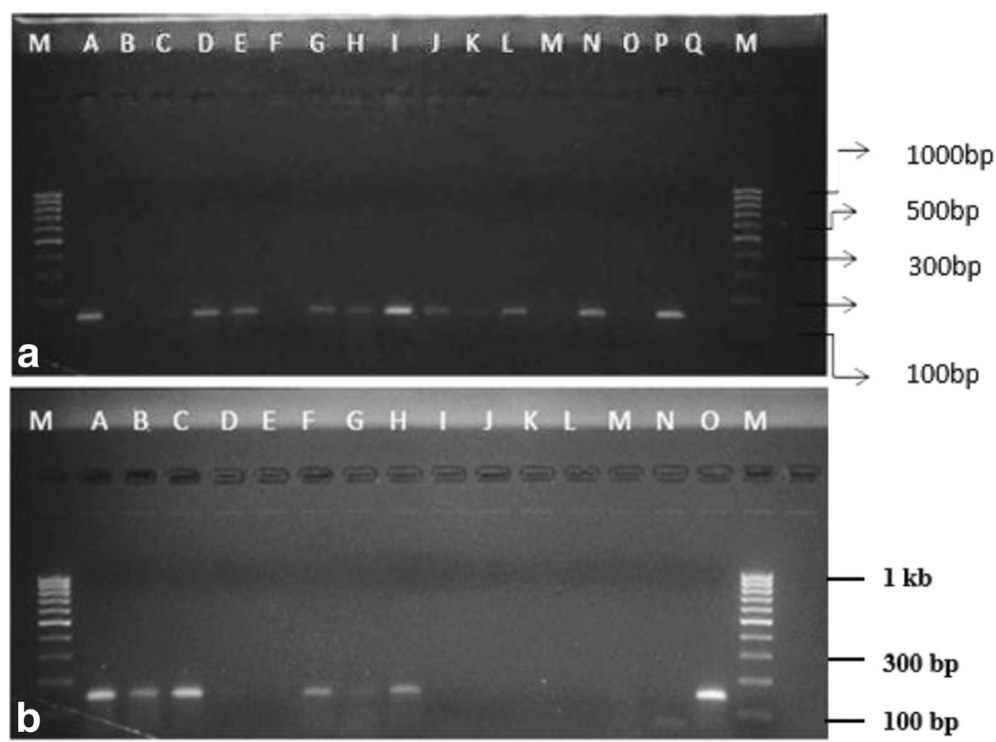

Fig. 1 a Amplification of a 163 bp gene fragment of methicillin resistance determinants (mecA) fragments of MRSA. b Gel image showing PCR amplification of 276 bp thermostable nuclease (nuc) and 533 bp methicillin resistance determinant (mecA) gene fragment

\section{Result}

\section{Antibiotic resistance profiles of donor, recipient, and transconjugants}

All isolates were catalase, tube coagulase and nuc positive. All donor cells were susceptible to levofloxacin while two isolates (SH4 and SDG3) were resistant to tigecycline and cefpodoxime and in addition to oxacillin, cefoxitin, erythromycin, amoxicillin and neomycin (Table 2). The recipient cells were all susceptible to erythromycin, amoxicillin and levofloxacin with the exception of one isolate (SCH4). Additionally, three isolates (SDG4, SH8 and SEQ1) were resistant to tigecycline, two (SDG4 and
SH8) for oxacillin and one isolate each (SEQ1, SH8) resistant to cefpodoxime, cefoxitin, and neomycin respectively (Table 2). The result of mix liquid culture plating on separate LB agar each containing antibiotics $100 \mu \mathrm{g} / \mathrm{mL}$ of erythromycin and cefpodoxime for selection of donor cells, tigecycline and levofloxacin for selection of recipient transconjugants, revealed two types of progeny cells; the donor cells which were resistant to erythromycin, cefpodoxime, oxacillin, cefoxitin, amoxicillin and neomycin and the recipient transconjugants were resistant to levofloxacin, tigecycline and neomycin. Similar result was obtained when the mix cultures were plated on LB agar containing

Table 2 Antibiotic susceptibility profile and mecA status of donor and recipient cells

\begin{tabular}{|c|c|c|c|c|c|c|c|c|c|c|}
\hline \multirow{2}{*}{$\frac{\mathrm{D}}{\text { Donor cells }}$} & \multicolumn{8}{|c|}{ Antibiotics Susceptibility profiles of donor cells } & \multirow[t]{2}{*}{ mecA } & \multirow{2}{*}{$\frac{\text { SCCmec }}{\text { Type III }}$} \\
\hline & OX & CPD & FOX & E & N & AML & TGC & LEV & & \\
\hline & 1 & 10 & 30 & 15 & 10 & 25 & 15 & 1 & & \\
\hline $\mathrm{SH} 1$ & $\mathrm{R}$ & $\mathrm{R}$ & $\mathrm{R}$ & $\mathrm{R}$ & $\mathrm{R}$ & $\mathrm{R}$ & $S$ & S & + & + \\
\hline $\mathrm{SH} 4$ & $\mathrm{R}$ & $\mathrm{R}$ & $\mathrm{R}$ & $\mathrm{R}$ & R & $\mathrm{R}$ & $\mathrm{R}$ & S & + & + \\
\hline SDG2 & $\mathrm{R}$ & S & $\mathrm{R}$ & $\mathrm{R}$ & $\mathrm{R}$ & $\mathrm{R}$ & S & S & + & + \\
\hline SDG3 & $\mathrm{R}$ & $\mathrm{R}$ & $\mathrm{R}$ & R & R & $\mathrm{R}$ & $\mathrm{R}$ & S & + & + \\
\hline SEV1 & $\mathrm{R}$ & S & $\mathrm{R}$ & $\mathrm{R}$ & $\mathrm{R}$ & $\mathrm{R}$ & S & S & + & + \\
\hline SEQ5 & $\mathrm{R}$ & S & S & $\mathrm{R}$ & R & $\mathrm{R}$ & S & S & + & + \\
\hline Recipient cells & \multicolumn{8}{|c|}{ Antibiotics resistance profiles of recipient cells } & mecA & Orfx \\
\hline SDG4 & $\mathrm{R}$ & S & S & S & S & S & $\mathrm{R}$ & S & - & + \\
\hline SH8 & $\mathrm{R}$ & $\mathrm{R}$ & $S$ & S & S & S & $\mathrm{R}$ & S & - & + \\
\hline $\mathrm{SCH} 4$ & S & S & S & $S$ & $S$ & S & $S$ & $\mathrm{R}$ & - & + \\
\hline SEQ1 & $S$ & $S$ & $\mathrm{R}$ & S & $R$ & $S$ & $\mathrm{R}$ & $S$ & - & + \\
\hline
\end{tabular}

SH human isolate, SDG dog isolate, SEV environmental isolate, SEQ horse isolate, $S C H$ chicken isolate, $R$ resistance, $S$ susceptible, E15 Erythromycin, CPD10 Cefpodoxime, FOX30 Cefoxitin, OX1 Oxacillin, N10 Neomycin, AML25 Amoxicillin, TGC15 Tigecycline, LEV1 Levofloxacin 
$50 \mu \mathrm{g} / \mathrm{mL}$ and $30 \mu \mathrm{g} / \mathrm{mL}$ respectively. However, there was no growth when SEQ5 and SEQ1 were plated on LB agar containing $100 \mu \mathrm{g} / \mathrm{mL}$ of erythromycin and tigecycline but, growth was observed when the same cultures were plated on LB agar containing $50 \mu \mathrm{g} / \mathrm{mL}$ and $30 \mu \mathrm{g} / \mathrm{mL}$ erythromycin and tigecycline. But, the transconjugants were all mecA negative (Table 4).

\section{Methicillin resistance determinants (mecA) profiles of donor, recipient, and transconjugants}

All donors used in this study were mecA positive and have the staphylococcal cassette chromosome mec a mobile genetic elements that harbors the mecA a determinant of methicillin resistance (Fig. 2). The presence of this structure in each donor isolate is to further confirm that the donor has the mecA gene. Additionally, the presence of mecA in the isolates helps to further categorize our isolates either as hospital acquired MRSA or community acquired MRSA. On the other hand, the recipient strains were $m e c \mathrm{~A}$ negative but positive for the orfX gene (Fig. 3). PCR amplification of methicillin resistance gene mecA after mix liquid plating on agar containing $100 \mu \mathrm{g} / \mathrm{mL}$ revealed that $75 \%$ (9) of the donor cells and $58.3 \%$ (7) of the recipient transconjugants cells were positive for mecA (Table 2). However, when cultures where plated on agar containing $50 \mu \mathrm{g} / \mathrm{mL}$ and $30 \mu \mathrm{g} / \mathrm{mL}$ respectively, $61.5 \%$ (8) of both the donor cells and recipient transconjugants were positive for mecA while only $46.2 \%$ (7) and $41.75 \%(5)$ of both donor cells and recipient transconjugants were mecA positive (Table 3 ).

Validation of the mecA status of the progeny daughter cells The methicillin resistance determinants mecA of progeny daughter cells after mixed liquid culture plating were determined using PCR assay. The amplified PCR products were then sequenced and analysed and the resultant consensus sequences shows 100\% similarity in the nucleotide identity with the parent donor and recipient cells.

\section{Discussion}

The rapid acquisition and worldwide dissemination of resistance determinants in MRSA is becoming a major veterinary and public health problem. This study was designed to investigate the in vitro transfer of antibiotic resistance from methicillin resistant $S$. aureus (MRSA) to a methicillin susceptible $S$. aureus (MSSA) using mix liquid culture plating. A number of studies have demonstrated the significance of horizontal transfer of resistance determinants from MRSA to MSSA as well as the role of PCR and selective antibiotics resistance markers in determining the direction of transfer [17-19].

In this study, growth observed on plates on LB agar containing $100 \mu \mathrm{g} / \mathrm{mL}$ of erythromycin-tigecycline, erythromycin-levofloxacin and cefpodoxime-levofloxacin each were considered as the transconjugants. Colonies on erythromycin and cefpodoxime plates were considered as donor cells while colonies that grow on tigecycline and levofloxacin plates were considered as recipient cells or transconjugants respectively. The antibiotic susceptibility profiles of the transconjugants when a dog isolate SDG2 serving as the donor strain was combined in a mix liquid culture plating with a human isolates SH8 serving as the recipient strain, revealed a transconjugants with a similar resistant profile to that of the donor strain as shown in (Table 4). The transconjugants were resistant to oxacillin, cefoxitin, erythromycin, amoxicillin, cefpodoxime, neomycin and tigecycline but sensitive to levofloxacin. Similar result was obtained when the same donor SDG2 was combined in a mix liquid culture plating with a different recipient strain SDG4 both isolated from dog. All the transconjugants were mecA positive, thus, indicating that transfer of methicillin resistance between the donors to recipient cell had occurred. Phenotypic transfer of cefoxitin, cefpodoxime, and erythromycin and amoxicillin resistance was also observed to have occurred from the donor strain to the recipient strains. Transfer of phenotypic resistance to tigecycline was also observed to have occurred from the recipient to the donor strain. This

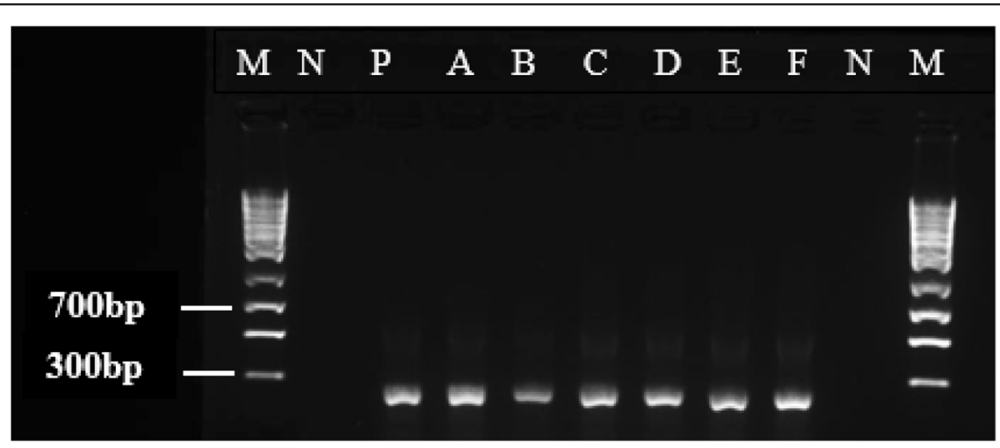

Fig. 2 PCR amplification of a 356 bp gene fragment of the universal insertion site of SCCmec or open reading frame (orfX) 


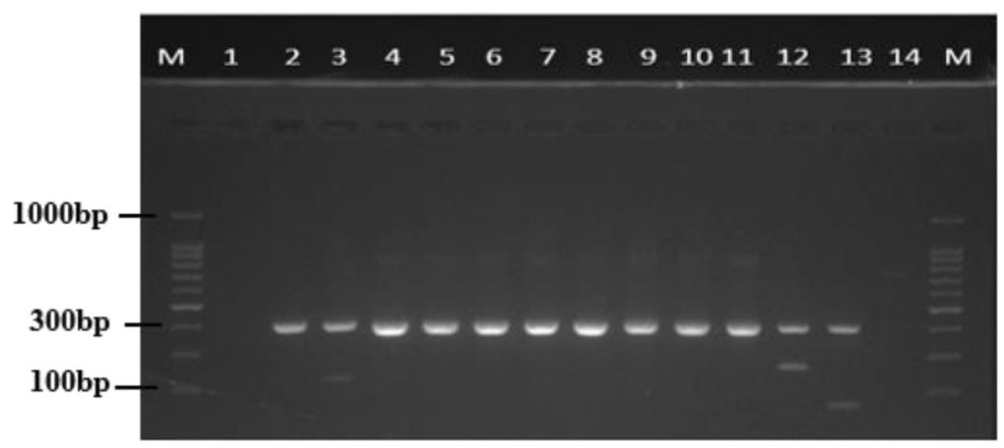

Fig. 3 Electropherograph of a 280 bp gene fragment of Staphylococcus cassette chromosome mec type III

transfer was possible, because resistance to beta lactams and macrolides antibiotics are plasmid coded and transfer of resistance have been known to have occurred in the absence of detectable conjugative plasmid [4]. Majority of MRSA possesses the conjugative plasmid belonging to the PGO1/pSK41 lineage which carries an identical transfer gene and oriT sequences. These plasmids carry multiple antibiotic resistance genes which are known to be transferable between different staphylococcal species [20]. In addition, conjugative plasmid transfer and transposition of resistance gene have been reported in $S$. aureus [21]. Similar result was obtained when the mix cultures were plated on LB agar containing $50 \mu \mathrm{g} /$ $\mathrm{mL}$ and $30 \mu \mathrm{g} / \mathrm{mL}$ of appropriate antibiotics however only one (SH8) of the two recipient transconjugants was positive for mecA gene. Even though MRSA does not have a detectable conjugative plasmids coding for the tra gene as in other bacteria which facilitate the transfer of resistance gene and subsequent emergence of strains with new form of resistance characteristics, evidence abounds that gene transfer events have been reported to have occurred $[4,22]$. Therefore, this may be due to the transfer of phenotypic resistance as well as determinants of methicillin resistance mecA between the donor and recipient strains was possible.

However, when another dog isolate SDG3 was used as the donor strain and combined with poultry isolate $\mathrm{SCH} 4$ resistant to levofloxacin as recipient strain in a mix liquid culture plating, the donor transconjugants had a similar profile with the parent donor strain which was resistant to oxacillin, cefoxitin, cefpodoxime, tigecycline, erythromycin, amoxicillin and neomycin while the recipient transconjugants was resistant to tigecycline, levofloxacin and neomycin a profile similar to the recipient parent strain. Similar results was observed when grown on agar containing $50 \mu \mathrm{g} / \mathrm{mL}$ and $30 \mu \mathrm{g} / \mathrm{mL}$ of appropriate antibiotics but, the recipient transconjugants were mecA negative. In each case phenotypic antibiotics resistance transfer was observed to have occurred in both direction, with the donor strain transferring resistance to neomycin and tigecycline while the recipient transferred levofloxacin resistance to the donor. Plasmid transfer of resistance to tetracycline, macrolide and quinolones have been reported to have occurred in $S$. aureus but, at a lower frequency [16, 23, 24]. The resistance to levofloxacin observed in donor transconjugants indicate that phenotypic transfer of resistance to levofloxacin have occurred from the recipient strain to the donor strain and so the direction of transfer can be said to be from recipient poultry isolate to donor poultry isolate while the inability of $m e c \mathrm{~A}$ transfer could be due restriction modification system inherent in the isolates [25] as transfer of resistant determinants is only possible between $S$. aureus of the same cluster even though the parent donor and recipient cells were both sourced from animal, yet can be different sequence type.

When a donor cell isolated from the environmental (SEV1) and SCH4 as recipient strains were combined, the transconjugants observed upon plating on agar containing $100 \mu \mathrm{g} / \mathrm{mL}$ and $50 \mu \mathrm{g} / \mathrm{mL}$ of the appropriate

Table 3 Methicillin resistance determinants mecA of donor and recipient transconjugants

\begin{tabular}{llll}
\hline SN & Cell type & Concentration of Antibiotic & mecA \\
\hline 1 & Donor transconjugants & $100 \mu \mathrm{g} / \mathrm{mL}$ & $9 / 12(75 \%)$ \\
& Recipient transconjugants & $100 \mu \mathrm{g} / \mathrm{mL}$ & $7 / 12(58.3 \%)$ \\
2 & Donor transconjugants & $50 \mu \mathrm{g} / \mathrm{mL}$ & $8 / 13(61.5 \%)$ \\
& Recipient transconjugants & $50 \mu \mathrm{g} / \mathrm{mL}$ & $8 / 13(61.5 \%)$ \\
3 & Donor transconjugants & $30 \mu \mathrm{g} / \mathrm{mL}$ & $7 / 15(46.2 \%)$ \\
& Recipient transconjugants & $30 \mu \mathrm{g} / \mathrm{mL}$ & $5 / 15(33.33 \%)$ \\
\hline
\end{tabular}


Table 4 Antibiotic susceptibility profile and mecA status of donor, recipient and transconjugants

\begin{tabular}{|c|c|c|c|c|c|c|c|c|c|c|}
\hline \multirow[t]{2}{*}{ Cell type } & \multirow[t]{2}{*}{ ID } & \multirow[b]{2}{*}{ OX1 } & \multicolumn{7}{|c|}{ Antibiotic susceptibility profiles } & \multirow[t]{2}{*}{ mecA } \\
\hline & & & CPD10 & $\mathrm{FOX} 3 \mathrm{O}$ & E15 & N10 & AML25 & TGC15 & LEV & \\
\hline Donor & SEQ5 & $\mathrm{R}$ & S & S & $\mathrm{R}$ & $\mathrm{R}$ & $\mathrm{R}$ & $S$ & S & + \\
\hline Recipient & $\mathrm{SCH} 4$ & $\mathrm{~S}$ & $S$ & $S$ & $S$ & $S$ & $S$ & $S$ & $\mathrm{R}$ & - \\
\hline (D)Transconjugants & E30 & $\mathrm{R}$ & $\mathrm{R}$ & S & S & $\mathrm{R}$ & $\mathrm{R}$ & $\mathrm{R}$ & S & - \\
\hline (R)Transconjugants & T30 & $\mathrm{R}$ & $S$ & S & $S$ & $\mathrm{R}$ & $\mathrm{R}$ & $\mathrm{R}$ & $S$ & - \\
\hline Donor & SEQ5 & $\mathrm{R}$ & S & S & $\mathrm{R}$ & $\mathrm{R}$ & $\mathrm{R}$ & S & S & + \\
\hline Recipient cell & SEQ1 & $S$ & $S$ & $S$ & S & $S$ & S & $S$ & $S$ & - \\
\hline (D)Transconjugant & E30 & $S$ & । & S & S & $\mathrm{R}$ & $\mathrm{R}$ & $\mathrm{R}$ & S & - \\
\hline (R)Transconjugant & T30 & $S$ & S & S & । & $\mathrm{R}$ & $\mathrm{R}$ & $\mathrm{R}$ & S & - \\
\hline Donor cells & SEV1 & $\mathrm{R}$ & $S$ & $\mathrm{R}$ & $\mathrm{R}$ & $\mathrm{R}$ & $\mathrm{R}$ & $\mathrm{S}$ & $S$ & + \\
\hline Recipient cells & SEQ1 & S & S & $\mathrm{R}$ & S & $\mathrm{R}$ & S & $\mathrm{R}$ & S & - \\
\hline (D)Transconjugants & E30 & $\mathrm{R}$ & $\mathrm{R}$ & $\mathrm{R}$ & $\mathrm{R}$ & $\mathrm{R}$ & $\mathrm{R}$ & $\mathrm{R}$ & S & - \\
\hline (R)Transconjugants & T30 & $\mathrm{R}$ & $\mathrm{R}$ & $\mathrm{R}$ & $\mathrm{R}$ & $\mathrm{R}$ & $\mathrm{R}$ & $\mathrm{R}$ & S & - \\
\hline Donor & SEQ5 & $\mathrm{R}$ & $S$ & S & $\mathrm{R}$ & $\mathrm{R}$ & $\mathrm{R}$ & $\mathrm{S}$ & $S$ & + \\
\hline Recipient & $\mathrm{SCH} 4$ & $\mathrm{R}$ & S & S & S & S & S & $\mathrm{R}$ & S & + \\
\hline (D)Transconjugants & E50 & ND & ND & ND & ND & ND & ND & ND & ND & ND \\
\hline (R)Transconjugants & T50 & $S$ & S & S & S & $\mathrm{R}$ & $\mathrm{R}$ & $\mathrm{R}$ & S & - \\
\hline Donor & SEQ5 & $\mathrm{R}$ & S & S & $\mathrm{R}$ & $\mathrm{R}$ & $\mathrm{R}$ & $S$ & S & + \\
\hline Recipient cell & SEQ1 & S & S & $\mathrm{R}$ & S & $\mathrm{R}$ & S & $\mathrm{R}$ & S & - \\
\hline (D)Transconjugant & E50 & ND & ND & ND & ND & ND & ND & ND & ND & ND \\
\hline (R)Transconjugant & T50 & $\mathrm{R}$ & I & S & 1 & $\mathrm{R}$ & $\mathrm{R}$ & $\mathrm{R}$ & $S$ & + \\
\hline Donor cells & SEV1 & $\mathrm{R}$ & S & $\mathrm{R}$ & $\mathrm{R}$ & $\mathrm{R}$ & $\mathrm{R}$ & $S$ & S & + \\
\hline Recipient cells & SEQ1 & S & S & $\mathrm{R}$ & S & $\mathrm{R}$ & S & $\mathrm{R}$ & S & - \\
\hline (D)Transconjugants & E50 & $\mathrm{R}$ & $\mathrm{R}$ & $\mathrm{R}$ & $\mathrm{R}$ & $\mathrm{R}$ & $\mathrm{R}$ & $\mathrm{R}$ & $S$ & - \\
\hline (R)Transconjugants & T50 & $\mathrm{R}$ & $\mathrm{R}$ & $\mathrm{R}$ & $\mathrm{R}$ & $\mathrm{R}$ & $\mathrm{R}$ & $\mathrm{R}$ & S & - \\
\hline Donor & SEQ5 & $\mathrm{R}$ & $S$ & $S$ & $\mathrm{R}$ & $\mathrm{R}$ & $\mathrm{R}$ & $\mathrm{S}$ & S & + \\
\hline Recipient & $\mathrm{SCH} 4$ & $\mathrm{R}$ & $S$ & S & S & $S$ & S & $\mathrm{R}$ & $S$ & + \\
\hline (D)Transconjugants & E100 & ND & ND & ND & ND & ND & ND & ND & ND & ND \\
\hline (R)Transconjugants & T100 & S & S & S & S & $\mathrm{R}$ & $\mathrm{R}$ & $\mathrm{R}$ & S & - \\
\hline Donor & SEQ5 & ND & ND & ND & ND & ND & ND & ND & ND & ND \\
\hline Recipient cell & SEQ1 & ND & ND & ND & ND & ND & ND & ND & ND & ND \\
\hline (D)Transconjugant & E100 & ND & ND & ND & ND & ND & ND & ND & ND & ND \\
\hline (R)Transconjugant & T100 & ND & ND & ND & ND & ND & ND & ND & ND & ND \\
\hline Donor cells & SEV1 & ND & ND & ND & ND & ND & ND & ND & ND & ND \\
\hline Recipient cells & SEQ1 & ND & ND & ND & ND & ND & ND & ND & ND & ND \\
\hline (D)Transconjugants & E100 & ND & ND & ND & ND & ND & ND & ND & ND & ND \\
\hline (R)Transconjugants & T100 & ND & ND & ND & ND & ND & ND & ND & ND & ND \\
\hline
\end{tabular}

ND Not determined, SH Staphylococcus human isolate, SDG staphylococcus dog isolate, SCH staphylococcus chicken isolate, SEV staphylococcus environmental isolate, SEQ staphylococcus equine/horse isolate, $100,50,30$ concentration of antibiotics in $\mu \mathrm{g} / \mathrm{mL}, D$ donors, $R$ recipients, $D$ Transconjugants donor transconjugants, $R$ Transconjugants recipient transconjugants, $R$ resistance, $S$ susceptible, I intermediate resistance, E15 erythromycin, CPD10 cefpodoxime, Lev 1 levofloxacin, TGC15 tigecycline

antibiotic resistance marker had profiles similar to both the donor and recipient parent cell and were mecA negative. Moreover, the transconjugants on plate containing $30 \mu \mathrm{g} / \mathrm{mL}$ antibiotics had resistance profile similar to the parent donor cells and were mecA positive
(Table 4). The presence of mecA positive transconjugants when $\mathrm{SCH} 4$ was used as a recipient cell on agar containing $30 \mu \mathrm{g} / \mathrm{mL}$ of antibiotics could possibly be due to the fact that there was actual transfer of mecA from the parent donor cell to the parent recipient cells which 
was not observed when same isolates were plated on agar containing 100 and $50 \mu \mathrm{g} / \mathrm{mL}$ probably due to the higher concentration of the antibiotics. Thus, the rational for using different concentration of antibiotics, because each isolate had different minimum inhibitory concentration. This was however, not the case when the same donor (SEV1) was combined with a different recipient strain. It was observed that both the donor and recipient transconjugants were resistant to oxacillin, cefoxitin, cefpodoxime, erythromycin, amoxicillin and neomycin but sensitive to tigecycline and levofloxacin a profile similar to the parent donor strain. This however, shows that the transconjugants were more closely related to the parent donor than the recipient. The direction of transfer could not be established since both the donor and recipient transconjugants were susceptible to tigecycline and levofloxacin even though they were mecA positive. This was consistent with the findings of Sabet et al. [18] where he reported a transconjugants with resistance phenotype different from either the parent donor or recipient. From the results obtained it can be inferred that there was no antibiotic resistance transfer from MRSA to MSSA of animals' origin and this could be due to the difference in strain or clonal class. The susceptibility of both the donor and recipient cells could be due to the concentration of the antibiotics in the two medium.

Likewise, when a horse isolate SEQ5 was used as the parent donor with a poultry isolate $\mathrm{SCH} 4$ and another horse isolate SEQ1 as recipients there was no growth observed on the LB agar containing the donor antibiotic resistant marker erythromycin. Similar result was also obtained when the concentration of the antibiotic marker was used at $50 \mu \mathrm{g} / \mathrm{mL}$ (Table 4). However, the recipient transconjugants had profiles similar to the parent recipient cells and all with the exception of one isolates were all mecA negative. However, this was not the case when the plating was done on $30 \mu \mathrm{g} / \mathrm{mL}$ of appropriate antibiotic resistance marker; the transconjugants observed were having profiles similar to either of the parent cells and were mecA negative. When the same donor was used with a dog isolate as recipient the transconjugants obtained were all mecA negative with profiles similar to both the parent and recipient cells. The inability of transfer to have occurred from the donor to the recipient strains could be the result of the presence of restriction system inherent in the bacteria, restriction system allows the integration of acquired gene to thrive only from bacteria of the same cluster [26]. The presence of an oxacillin positive mecA negative strain can occur due to the presence of the presence of a small colony variants of oxacillin resistant strains which occurred as a result of over production of penicillin binding protein rather than the acquisition of mecA from the donor strains. Additionally, resistance to oxacillin could also occur due to external factors such as the content of the medium which could slightly affect the outcome of the result as an increase in $\pm 0.1 \mathrm{~mm}$ in the diameter of inhibition could alter the resistance profile of the isolate.

Furthermore on investigating antibiotic resistance transfer using two of the human isolates ( $\mathrm{SH} 1$ and $\mathrm{SH} 4)$ as donor cells with three isolates (SH8, SGD4 and $\mathrm{SCH} 4)$ serving as recipients cells. The transconjugants obtained when SH1 was combined with SDG4, and SH1 with $\mathrm{SH} 8$ all had resistance profiles similar to the parent donor transconjugants and were all mecA positive. However, when SH4 was combined SCH4, the donor transconjugants had profiles similar to the parent donor cells and the recipient transconjugants also had profiles similar to the recipient parent cells and were mecA positive. Similar result was also obtained when mix culture was plated on agar containing $50 \mu \mathrm{g} / \mathrm{mL}$ and $30 \mu \mathrm{g} / \mathrm{mL}$ of antibiotic resistance marker (Table 5). This is in agreement with work

Table 5 Antibiotic susceptibility profiles and mecA status of donor and recipient transconjugants

\begin{tabular}{|c|c|c|c|c|c|c|c|c|c|}
\hline \multirow[t]{2}{*}{ Cell type } & \multirow[t]{2}{*}{ ID } & \multicolumn{7}{|c|}{ Antibiotic profiles of transconjugants } & \multirow[t]{2}{*}{ mecA } \\
\hline & & OX1 & CPD10 & $\mathrm{FOX3O}$ & E15 & N10 & AML25 & TGC15 & \\
\hline (D)Transconjugant & $1 \mathrm{E}$ & $\mathrm{R}$ & $\mathrm{R}$ & $\mathrm{R}$ & $\mathrm{R}$ & $\mathrm{R}$ & I & $\mathrm{S}$ & + \\
\hline (R)Transconjugant & $1 \mathrm{~T}$ & $\mathrm{R}$ & $\mathrm{R}$ & $\mathrm{R}$ & $\mathrm{R}$ & $\mathrm{R}$ & । & $\mathrm{R}$ & + \\
\hline (D)Transconjugant & $2 \mathrm{E}$ & $\mathrm{R}$ & $\mathrm{R}$ & $\mathrm{R}$ & $\mathrm{R}$ & $\mathrm{R}$ & $\mathrm{R}$ & $\mathrm{R}$ & + \\
\hline (R)Transconjugant & $2 \mathrm{~T}$ & $\mathrm{R}$ & $\mathrm{R}$ & $\mathrm{R}$ & $\mathrm{R}$ & $\mathrm{R}$ & I & S & + \\
\hline (D)Transconjugant & $3 \mathrm{E}$ & $\mathrm{R}$ & $\mathrm{R}$ & $\mathrm{R}$ & $\mathrm{R}$ & $\mathrm{R}$ & $\mathrm{R}$ & $\mathrm{S}$ & + \\
\hline (R)Transconjugant & $3 \mathrm{~T}$ & $R$ & $\mathrm{R}$ & $\mathrm{R}$ & $\mathrm{R}$ & $\mathrm{R}$ & $\mathrm{R}$ & S & - \\
\hline (D)Transconjugant & $4 \mathrm{E}$ & $R$ & $R$ & $\mathrm{R}$ & $\mathrm{R}$ & $R$ & । & $\mathrm{R}$ & + \\
\hline (R)Transconjugant & $4 \mathrm{~T}$ & S & $S$ & S & S & S & $\mathrm{R}$ & $\mathrm{R}$ & - \\
\hline (D)Transconjugant & $5 \mathrm{E}$ & $\mathrm{R}$ & $\mathrm{R}$ & $\mathrm{R}$ & $\mathrm{R}$ & $\mathrm{R}$ & $S$ & $\mathrm{~S}$ & + \\
\hline (R)Transconjugant & $5 \mathrm{~T}$ & $\mathrm{R}$ & $\mathrm{R}$ & $\mathrm{R}$ & $\mathrm{R}$ & $\mathrm{R}$ & $\mathrm{R}$ & $\mathrm{R}$ & + \\
\hline
\end{tabular}

Transconjugants $(A)$ donor transconjugants, Transconjugants $(B)$ recipient transconjugants, $E, T$, agar concentration of erythromycin and tigecycline in $\mu g / m L, D$ donors, $R$ recipients, $D R$ resistance, $S$ susceptible, $I$ intermediate resistance 
of Khan et al. [17] where he demonstrated the in vitro transfer of erythromycin resistance from a clinical strain to poultry strain. The similarity observed in resistance profiles showed that the transconjugants were closely related to the donor strain than the recipient strain, however, the transfer of mecA shows that the direction of methicillin resistance transfer was from the human to animal isolate.

\section{Conclusion}

The use of PCR and antibiotic markers have enable us to determine the direction of transfer of resistance between MRSA and MSSA, however, the different concentration of the antibiotics used did not significantly affect the rate of transfer, as the difference in mecA status of the recipient transconjugants were not much. In this study, it was established that transfer of methicillin resistance determinants mecA have occurred from MRSA to MSSA at different concentration of antibiotic resistance marker.

\begin{abstract}
Abbreviations
MRSA: Methicillin resistant Staphylococcus aureus; MSSA: Methicillin susceptible Staphylococcus aureus; PCR: Polymerase chain reaction; LB: LuriaBertini; OrfX: Open reading frame of unknown origin

SCCmec: Staphylococcal cassette chromosome mec; UV: Ultra violet; CFU: colony forming unit; DNA: Deoxyribonucleic acid; CLSI: Clinical laboratory standard institute; ORSAB: Oxacillin resistance screening agar base
\end{abstract}

\section{Acknowledgments}

The authors thank the laboratory staff at Bacteriology Laboratory, Department of Veterinary Pathology and Microbiology, Faculty of Veterinary Medicine, Universiti Putra Malaysia, for their kind cooperation throughout the course of this study.

\section{Funding}

This research has been supported by Universiti Putra Malaysia's Putra Grant (9428800) and Fundamental Research Grant Scheme, MOHE (5524643). The funds provided by the funding bodies helped in the design, data collection, analysis and interpretation of results.

\section{Availability of data and materials}

The dataset during and/or analysed during the current study available from the corresponding author on reasonable request.

\section{Authors' contribution \\ $A A B$ designed and carried out the experiment and drafted the manuscript, ZZ designed the work, provided the fund, some of the isolates and critically analyzed the manuscript, SKB designed the work, provided access to the equipment and critically analyzed the manuscript, SO designed the work, critically analysed the manuscript and provided guidance, and NAN provided some of the isolates. Additionally, the authors have read and approved the final version of this manuscript.}

\section{Competing interest}

The authors declare that they have no competing interest in this section.

\section{Consent for publication}

Not applicable in this section.

Ethics approval and consent to participate

Not applicable in this section.

\section{Publisher's Note}

Springer Nature remains neutral with regard to jurisdictional claims in published maps and institutional affiliations.

\section{Author details}

${ }^{1}$ Faculty of Veterinary Medicine, Universiti Putra Malaysia, 43400 UPM Serdang, Malaysia. 'Faculty of Biotechnology and Biomolecular Sciences, Universiti Putra Malaysia, 43400 UPM Serdang, Malaysia.

Received: 12 August 2016 Accepted: 29 March 2017

Published online: 04 April 2017

\section{References}

1. Witte W. Ecological impact of antibiotic use in animals on different complex microflora: environment. Int J Antimicrob Agents. 2000;14(4):321-5.

2. Ohlsen K, Ternes T, Werner G, Wallner U, Löffler D, Ziebuhr W, Witte W, Hacker J. Impact of antibiotics on conjugational resistance gene transfer in Staphylococcus aureus in sewage. Environ Microbiol. 2003;5(8):711-6.

3. Berger-Bächi B, Rohrer S. Factors influencing methicillin resistance in staphylococci. Arch Microbiol. 2002;178(3):165-71.

4. Barlow M. What antimicrobial resistance has taught us about horizontal gene transfer. In: Horizontal Gene Transfer. Springer; 2009;397-411. doi:10.1007/978-1-60327-853-9.

5. Wang $L$, Archer GL. Roles of CcrA and CcrB in excision and integration of staphylococcal cassette chromosome mec, a Staphylococcus aureus genomic island. J Bacteriol. 2010;192(12):3204-12.

6. Chongtrakool P, Ito T, Ma XX, Kondo Y, Trakulsomboon S, Tiensasitorn C, Jamklang M, Chavalit T, Song J-H, Hiramatsu K. Staphylococcal cassette chromosome mec (SCCmec) typing of methicillin-resistant Staphylococcus aureus strains isolated in 11 Asian countries: a proposal for a new nomenclature for SCCmec elements. Antimicrob Agents Chemother. 2006: 50(3):1001-12

7. Chambers HF. Methicillin resistance in staphylococci: molecular and biochemical basis and clinical implications. Clin Microbiol Rev. 1997;10(4):781-91.

8. Hanssen AM, Ericson Sollid JU. SCCmec in staphylococci: genes on the move. FEMS Immunol Med Microbiol. 2006;46(1):8-20.

9. Aklilu E, Zunita Z, Hassan L, Cheng CH. Molecular epidemiology of methicillin-resistant Staphylococcus aureus (MRSA) among veterinary students and personnel at a veterinary hospital in Malaysia. Vet Microbiol. 2013;164(3-4):352-8.

10. Aklilu E, Zunita Z, Hassan L, Chen H. Phenotypic and genotypic characterization of methicillin-resistant Staphylococcus aureus (MRSA) isolated from dogs and cats at university veterinary hospital Universiti Putra Malaysia. Trop Biomed. 2010;27:483-92

11. Bauer A, Kirby W, Sherris JC, Turck M. Antibiotic susceptibility testing by a standardized single disk method. Am J Clin Pathol. 1966;45(4):493.

12. Clinical and Institute Laboratory Standards (CLSI). Performance standards for antimicrobial disc susceptibility tests; Approved Standard-11th Ed, M2-A9. Wayne, PA, USA. 2014

13. Chen L, Mediavilla JR, Oliveira DC, Willey BM, de Lencastre $H$, Kreiswirth BN. Multiplex real-time PCR for rapid staphylococcal cassette chromosome mec typing. J Clin Microbiol. 2009:47(11):3692-706.

14. Tom H. Biological sequence allignment editor for win 95/98/NT/2A/XP/7. 2013

15. Thompson JD, Gibson TJ, Plewniak F, Jeanmougin F, Higgins DG. The Clustal_X windows interface: flexible strategies for multiple sequence allignment aided by quality analysis tool. Nucleic Acid Research. 1997;25: 4876-82.

16. Gaisteiger E, Gattiker A, Hoogland C, Ivanyi I, Appel RD, Bairoch A. ExPASy: the proteomics server for depth protein knowledge and analysis. Nucleic Acid Research. 2003;31:3784-8.

17. Khan SA, Nawaz MS, Khan AA, Cerniglia CE. Transfer of erythromycin resistance from poultry to human clinical strains of Staphylococcus aureus. J Clin Microbiol. 2000:38(5):1832-8.

18. Sabet NS, Subramaniam G, Navaratnam P, Sekaran SD. In vitro mecA gene transfer among Staphylococcus aureus in Malaysian clinical isolates. Afr J Biotechnol. 2014;11(2):385-90.

19. Wielders C, Vriens M, Brisse S, de Graaf-Miltenburg L, Troelstra A, Fleer A Schmitz F, Verhoef J, Fluit A. Evidence for in-vivo transfer of mecA DNA between strains of Staphylococcus aureus. Lancet. 2001;357(9269):1674-5.

20. Ray M, Boundy S, Archer G. Transfer of the methicillin resistance genomic island among staphylococci by conjugation. Mol Microbiol 2016.

21. Edwards JS, Betts L, Frazier ML, Pollet RM, Kwong SM, Walton WG, Ballentine WK, Huang JJ, Habibi S, Del Campo M. Molecular basis of antibiotic multiresistance transfer in Staphylococcus aureus. Proc Natl Acad Sci. 2013; 110(8):2804-9. 
22. Forbes BA, Schaberg DR. Transfer of resistance plasmids from Staphylococcus epidermidis to Staphylococcus aureus: evidence for conjugative exchange of resistance. J Bacteriol. 1983;153(2):627-34.

23. Roberts MC. Update on acquired tetracycline resistance genes. FEMS Microbiol Lett. 2005;245(2):195-203.

24. Doškař J, Pantůček R, Rủžičková V, Sedláček I. Molecular Diagnostics of Staphylococcus aureus. In: Detection of Bacteria, Viruses, Parasites and Fungi. Springer; 2010;139-184. doi:10.1007/978-90-481-8544-3_7.

25. Lindsay JA. Evolution of Staphylococcus aureus and MRSA during outbreaks. Infect Genet Evol. 2014;21:548-53.

26. Huddleston JR. Horizontal gene transfer in the human gastrointestinal tract: potential spread of antibiotic resistance genes. Infect Drug Resist. 2014;7:167.

27. Noto MJ, Kreiswirth BN, Monk AB, Archer GL. Gene acquisition at the insertion site for $\mathrm{SCC}$ ec, the genomic island conferring methicillin resistance in Staphylococcus aureus. J Bacteriol. 2008:190(4):1276-83.

28. Mehrotra M, Wang G, Johnson WM. Multiplex PCR for Detection of genes for Staphylococcus aureus Enterotoxins, Exfoliative toxins, toxic shock syndrome toxin 1, and Methicillin resistance. J Clin Microbiol. 2000;38(3):1032-5

29. Saiful A, Mastura M, Zarizal S, Mazurah M, Shuhaimi M, Ali A. Detection of methicillin-resistant Staphylococcus aureus using mecA/nuc genes and antibiotic susceptibility profile of Malaysian clinical isolates. World J Microbiol Biotechnol. 2006;22(12):1289-94

30. Zhang K, McClure J-A, Conly JM. Enhanced multiplex PCR assay for typing of staphylococcal cassette chromosome mec types I to V in methicillinresistant Staphylococcus aureus. Mol Cell Probes. 2012;26(5):218-21.

Submit your next manuscript to BioMed Central and we will help you at every step:

- We accept pre-submission inquiries

- Our selector tool helps you to find the most relevant journal

- We provide round the clock customer support

- Convenient online submission

- Thorough peer review

- Inclusion in PubMed and all major indexing services

- Maximum visibility for your research

Submit your manuscript at www biomedcentral.com/submit

\section{O BioMed Central}

